\title{
Metabolic adaptation of animals from different lautitudes ${ }^{1}$
}

\author{
F. John Vernberg and Winona B. Vernberg \\ Duke University Marine Laboratory, Beaufort, North Carolina, \\ and Duke University, Durbam, North Carolina, USA
}

\begin{abstract}
KURZFASSUNG: Stoffwechseladaptation bei Tieren aus verschiedenen Breiten. In den Maße, in welchem sich die Verbreitungsgrenzen von Populationen ausweiten, verursachen neue Umweltstresse selektive Beeinflussungen. Es ist daher durchaus denkbar, daß latitudinal getrenntlebende Tier-Populationen sich allmählich in ihren physiologischen Reaktionen zu unterscheiden beginnen. Für einshlägige Studien erwiesen sich Kurzschwanzkrebse der Gattung Uca als sehr geeignet, da die Artvertreter sowohl Affinitäten zur gemäßigten Zone als auch zu tropischen Gebieten besitzen und hinsichtlich ihrer Verbreitung eine Uberlappungszone entlang der subtropischen Ostküste Zentral-Floridas (USA) besteht. Stoff wechselphysiologische Untersuchungen an Uca-Populationen von New York, North Carolina, Florida, Puerto Rico und Jamaika weisen darauf hin, daß tatsächlich eindeutige Unterschiede bestehen. Ganz allgemein reagieren Versuchstiere aus der gemäßigten Zone stoff wechselphysiologisch labiler, während tropische Arten stenothermer sind. Die Untersuchungen wurden durchgeführt über einen Bereïch verschiedener konstanter Temperaturen, und zwar sowohl an adulten Tieren und Larven als auch an verschiedenen Geweben (Herz, Muskel, Gehirn, Kieme und Mitteldarmdrüse). Die Beziehungen stoffwechselphysiologischer Reaktionen, welche zwischen Ganztier und Gewebe einerseits und den verschiedenen ontogenetischen Stadien andererseits gefunden wurden, erlauben einige Generalisierungen. Das Akklimatisationsmuster ist nicht bei allen Lebenszyklusstadien dasselbe. Die Gewebe zeigen nicht die gleichen stoffwechselphysiologischen Reaktionen wie das Ganztier. Eine uniforme Beziehung zwischen latitudinaler Verbreitung aller Arten oder Populationen und ihren Reaktionen ist nicht evident.
\end{abstract}

\section{INTRODUCTION}

As organisms attempt to extend their distributional limits, they are faced with a new complex of environmental stresses. If these new stresses are too extreme and an animal is unable to cope with them, the organism is unable to colonize. However, if the species has the prerequisite adaptive capacity, it may be successful and survive in the new area. At any location in the range of a species, unusual environmental fluctuations, such as burricanes (Wells 1961) or heavy rains (GoodBody 1961), may destroy populations, but normally animals at either end of the distributional limits

1. Supported by a number of grants from the National Science Foundation. A travel grant (GB-1444) from the NSF enabled this paper to be presented at the First International Sympositu on Problems of Quantitatioe Biology of Metabolism. Helgoland, Germany. 
appear most sensitive to changes in environmental factors. An example of this are "winter kills" of fish in Florida following unusually severe winter temperatures (Storey \& Gudger 1936, MrLler 1940).

The study of the physiological response of organisms to ecological factors is of basic importance in understanding the distribution of animals. Physiologically distinct populations may arise as a result of evolutionary processes operating differentially on latitudinally separated populations of one species. All observed variations in the physiological response of animals from different latitudes may not be genetic; rather these differences may reflect phenotypic expressions induced by different intensities of environmental factors acting in various latitudes. Therefore, it is important to differentiate between genotypic and phenotypic responses. To distinguish between these two responses, some useful information can be obtained by acclimation studies and/or by rearing animals under different environmental conditions.

Historically early significant work in the field of metabolic adaptation was done by Fox \& WingField (1936-1939), Spärck (1936), TAKatsuki (1928) and Thorson (1936). Since then an ever-increasing interest has been shown in the physiological differences of animal populations that are latitudinally separated (see review by VERNBERG 1962). These studies have taken diverse paths and stress various levels of biological organization: some deal with the response of the whole organism, some with the response of tissues, while still others stress biochemical changes. Because of the complexity of this subject, many of these studies are by necessity of a descriptive nature. In order to understand the mechanism(s) of metabolic adaptation, we must correlate and integrate the results of all these various approaches. Two problems in the field of quantitative biology of metabolism are: 1) to assess adequately the role of physiological variation when different populations of organisms are compared; and, 2) to determine which generalizations and models are valid when the metabolism of latitudinally separated animals is compared.

The present paper deals only with one aspect of this broad problem, i. e. metabolic adaptations to temperature. This topic is further delineated in that studies involving but one genus of decapod crustaceans, $U_{c a}$, will be emphasized. This paper represents an attempt to review the results of various published studies and unpublished data with the goal in mind of examining aspects of the quantitative metabolism of one genus which extends over a wide geographical range. Metabolic studies involving larval and adult fiddler crabs as well as tissues of these animals will be reviewed.

\section{ANIMALS STUDIED}

$U c a$ is a cosmopolitian genus which inhabits the intertidal zone and regions adjacent to marine waters. The various species show somewhat different habitat preferences. Species of this genus were selected for study for the following three reasons: a) the various species have either temperate zone or tropical zone affinities, and, in addition, there is an area of overlap of some northern and some southern forms along the northeast coast of Florida; b) each species is very abundant and in- 
dividuals are not too difficult to collect; c) animals are easily maintained in the laboratory.

The following species have been studied: Temperate zone species: Uca pugnax, Massachusetts to northeast Florida; Uca minax, Massachusetts to southern Florida; Uca pugilator, Massachusetts to southern Florida. Tropical zone species: Uca rapax, from northeast Florida to Brazil; Uca thayeri, from northeast Florida to Brazil; Uca mordax, from the Bahamas to Brazil; Uca leptodactyla, from the west coast of Florida to Brazil.

\section{METABOLIC STUDIES}

\section{Larval stages}

In a number of species larval stages tend to respond differently to certain physical factors in degree or manner from the adult stages (Costlow, Bookhout \& Monroe 1959, Mellanby 1940). Therefore, to assess the importance of a physical factor to

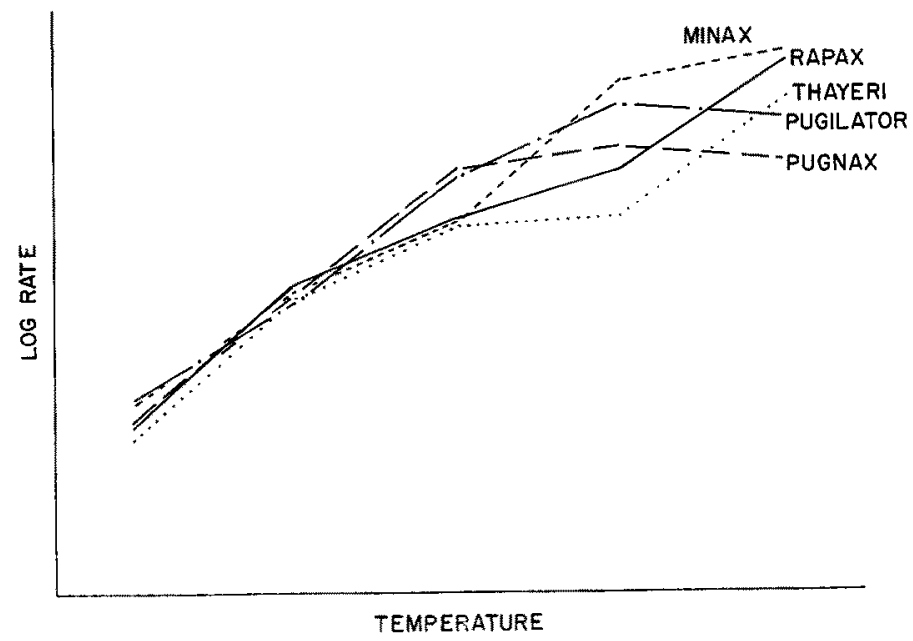

Fig. 1: The comparative metabolic-temperature curves of first stage zoea of various species of temperate zone and tropical zone fiddler crabs

an organism, the effect on all stages in the life cycle should be studied. This section of the paper will review the larval studies on Uca (VERnBRg \& Costlow, in preparation). All stages in the life-cycle of fiddler crabs are free-living; typically, there are five zoeal stages, one megalops, then the crab stage. Data are presented on two tropical zone species, $U$, rapax and $U$. thayeri, and on three temperate zone species. The temperate zone species include populations of $U$. minax from North Carolina, $U$. pugnax from North Carolina and New York, and U. pugilator from Florida, North Carolina and Massachusetts. 
Detailed descriptions of the rearing techniques and methods of determining metabolic rates are described by VERNBERG \& COSTLOw (in preparation). All the animals were reared at a temperature of $25^{\circ} \mathrm{C}$ and a salinity of $30 \mathrm{p}$. p. t.; this combination resulted in maximum survival and growth of all species. Metabolic rates were measured in microrespirometers after the method of Grunbaum et al. (1955).

\section{First stage zoea}

There were no striking differences in metabolic rates between tropical and North Carolina temperate zone zoea over a $15^{\circ}$ to $30^{\circ} \mathrm{C}$ temperature range (Fig. 1). However, when the temperature was increased from $30^{\circ}$ to $35^{\circ} \mathrm{C}$, the respiration rate of the tropical zone species increased slightly more than $50 \%$, while the Q02 of the zoea of temperate zone species remained relatively constant. The metabolic rates of $U$. pugilator zoea from Florida were intermediate between the temperate zone and tropical zone species at this temperature. These differences are reflected in $Q_{10}$ values. The

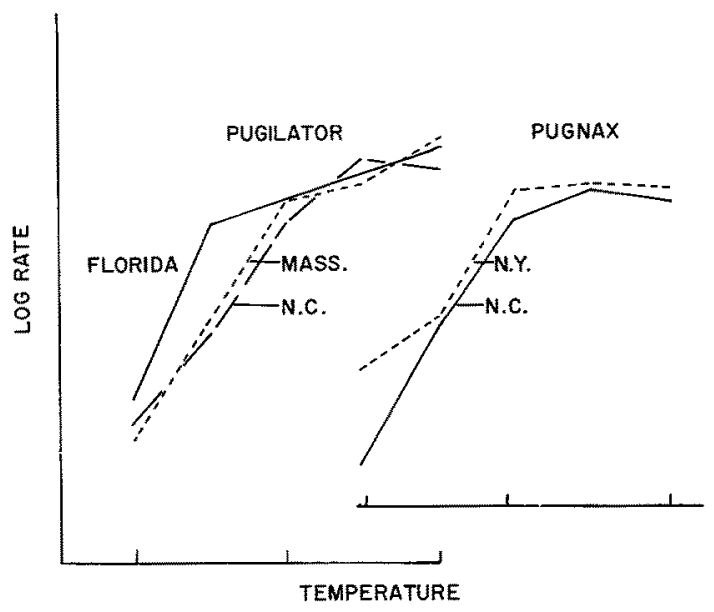

Fig. 2: The comparative metabolic-temperature curves of first stage zoea of latitudinally separated populations of fiddler crabs

Q10's of the tropical species were between 2.0 and 3.0, while the values of the Florida and temperate zone zoea, when the differences were great enough to calculate, were all less than 2.0 .

The most marked differences in the metabolism of latitudinally separated populations were observed in $U$. pugnax at lower temperatures (Fig. 2). The $\mathrm{Q}_{2}$ of zoea of crabs from New York was $35 \%$ higher than the respiration of zoea of the same species from North Carolina when measured at $15^{\circ} \mathrm{C}$. This could quite possibly be correlated with the lower water temperatures found in the New York area. These curves are typical for warm and cold-acclimated animals, i. e., in cold-acclimated or cold-adapted species the curve is displaced laterally to the left of warm-acclimated 
or warm-water forms. No generalization could be discerned in comparisons between tropical and temperate zoea at $15^{\circ} \mathrm{C}$, and in all species, except $U$. pugnax from New York, the respiration rate increased over $50 \%$ when the temperature was raised from $15^{\circ}$ to $20^{\circ} \mathrm{C}$ (Figs. 1 and 2). Perhaps this reflects the relatively warm temperatures to which even the temperate zone zoea would be exposed, since the zoea typically are released during the warmer months.

\section{Megalops}

It was not always possible to obtain large numbers of the megalops stage with all species; this was particularly true of $U$. pugnax from North Carolina. Although there was a limited number of $U$. pugnax megalops available, certain trends do seem to be apparent when larvae from New York and North Carolina are compared.

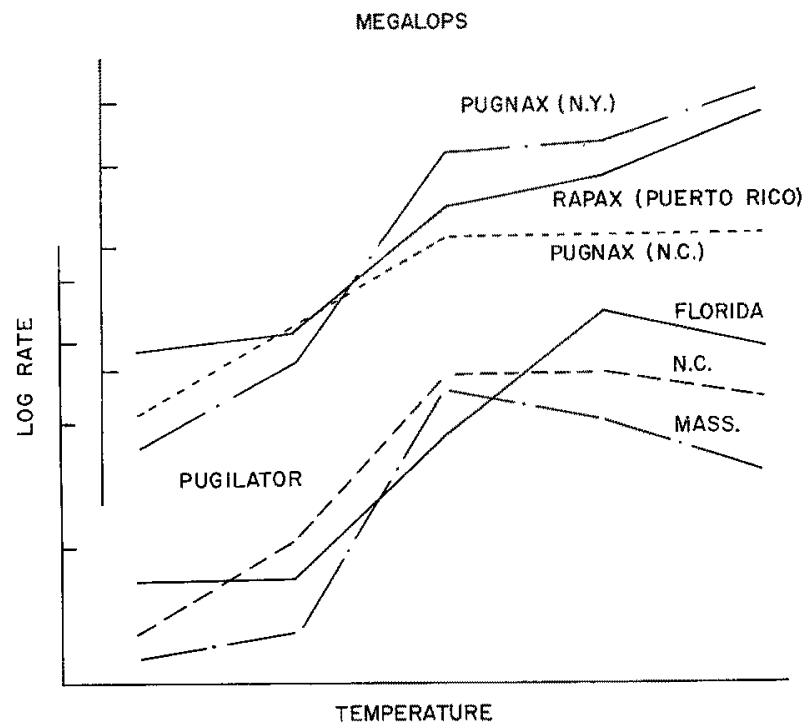

Fig. 3: The comparative metabolic-temperature curves of megalops of various species and populations of fiddler crabs

Whereas the zoea from these two populations differed markedly at $15^{\circ} \mathrm{C}$ but not at higher temperatures, the megalops stage had a similar response at $15^{\circ} \mathrm{C}$, but at $35^{\circ} \mathrm{C}$, the larvae from New York had a Qoo which was $41 \%$ higher than that of the North Carolina populations (Fig. 3).

The metabolic rate of the megalops stage from the three $U$. pugilator populations (Massachusetts, North Carolina and Florida) also differed somewhat from the response of the zoeal stages. The North Carolina larvae had consistently, but not always significantly, higher $\mathrm{QO}_{2}$ values than did the megalops from Massachusetts. The maximum $\mathrm{Q}_{2}$ values were obtained at different temperatures for each population. The 
highest respiration rate of larvae from Massachusetts was reached at $25^{\circ} \mathrm{C}$, for those from North Carolina the highest rates were at $25^{\circ}$ and $30^{\circ} \mathrm{C}$, and the megalops from Florida reached a maximum Qog at $30^{\circ} \mathrm{C}$. Florida megalops also had the highest values of the three populations at $15^{\circ} \mathrm{C}$.

The megalops stage of $U$. rapax responded very much the same as did the zoeal stage at the higher temperatures; the highest respiration for both was obtained at $35^{\circ} \mathrm{C}$. At $15^{\circ}$ and $20^{\circ} \mathrm{C}$, however, the pattern shifted. The Q02 of the zoea increased $70 \%$ when the temperature was raised to $200 \mathrm{C}$, but in the megalops stage the respiration rate was still depressed at $20^{\circ} \mathrm{C}$ and increased only $9 \%$ over that measured at $15^{\circ} \mathrm{C}$.

\section{Young crabs}

After the megalops metamorphosed into the young crab stage, a new pattern of metabolic response emerged among the three populations of $U$. pugilator (Fig. 4). Crabs from the Florida population had the lowest metabolic rate, the ones from Mas-

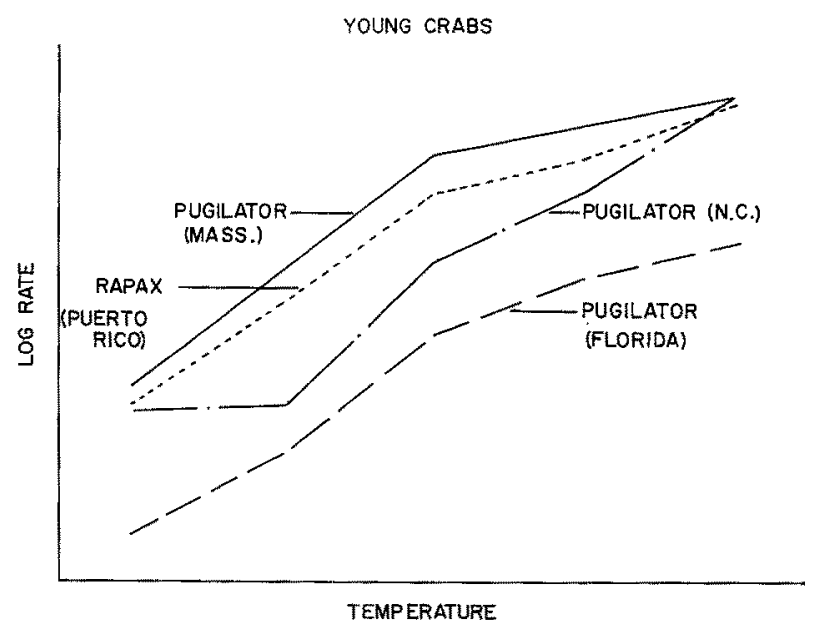

Fig. 4: The comparative metabolic-temperature curves of young crabs of various populations and species of fiddler crabs

sachusetts the highest rate. In all three populations the maximum $\mathrm{QO}_{2}$ was obtained at $30^{\circ} \mathrm{C}$. Comparable data are not available for $U$. pugnax. The young crabs of $U$. rapax responded very much in the same manner as the megalops stage.

\section{Adults}

A series of metabolic-temperature (M-T) curves is presented in Figure 5 showing the pattern of acclimation in adult $U c a$ as reported by Demeusy (1957) and VERN- 
Table 1

Comparisons of patterns of acclimation in $U c a$

\begin{tabular}{|c|c|c|c|c|}
\hline species & $\begin{array}{l}\text { stage of } \\
\text { life cycle } \\
\text { or type of } \\
\text { tissue }\end{array}$ & $\begin{array}{l}\text { pattern } \\
\text { number } \\
\text { (according } \\
\text { to Prosser) }\end{array}$ & comment & reference \\
\hline pugilator & adults & II $\mathrm{A}$ & $\begin{array}{l}\text { populations from } \\
\text { Mass. \& Fla. }\end{array}$ & Demeusy (1957) \\
\hline pugilator & young adults & II A & $\begin{array}{l}\text { populations from } \\
\text { Mass., N.C. \& Fla. }\end{array}$ & $\begin{array}{l}\text { VERNBERG \& CoSTLOW } \\
\text { (in preparation) }\end{array}$ \\
\hline rapax & adult & $\begin{array}{l}\text { I or } \\
\text { III B }\end{array}$ & $\begin{array}{l}\text { animals from } \\
\text { Jamaica }\end{array}$ & VERNBERG $(1959)$ \\
\hline rapax & adult & III A & $\begin{array}{l}\text { animals from } \\
\text { Fla. }\end{array}$ & VERNBERG (1959) \\
\hline pugnax & adult & IV A & $\begin{array}{l}\text { animals from } \\
\text { N.C. }\end{array}$ & VERNBERG (1959) \\
\hline pugnax & adult & II A & $\begin{array}{l}\text { populations from } \\
\text { N.Y. \& N.C. }\end{array}$ & TASHIAN (1956) \\
\hline $\operatorname{rapax}$ & adult & II A & $\begin{array}{l}\text { populations from } \\
\text { Fla. \& Trinidad }\end{array}$ & TAShian (1956) \\
\hline pugilator & $\begin{array}{l}\text { 1st stage } \\
\text { zoea }\end{array}$ & IV D & $\begin{array}{l}\text { populations from } \\
\text { Fla. \& N.C. (or Mass.) }\end{array}$ & $\begin{array}{l}\text { VERNBERG \& COSTLOW } \\
\text { (in preparation) }\end{array}$ \\
\hline pugilator & $\begin{array}{l}\text { 1st stage } \\
\text { zoea }\end{array}$ & I & $\begin{array}{l}\text { populations from } \\
\text { N.C. \& Mass. }\end{array}$ & $\begin{array}{l}\text { VeRnBERG \& Costlow } \\
\text { (in preparation) }\end{array}$ \\
\hline pugnax & $\begin{array}{l}\text { 1st stage } \\
\text { zoea }\end{array}$ & IV A & $\begin{array}{l}\text { populations from } \\
\text { N.Y. \& N.C. }\end{array}$ & $\begin{array}{l}\text { VERNBERG \& COSTLOW } \\
\text { (in preparation) }\end{array}$ \\
\hline $\begin{array}{l}5 \text { species } \\
\text { of Uca }\end{array}$ & $\begin{array}{l}\text { 1st stage } \\
\text { zoea }\end{array}$ & I & $\begin{array}{l}\text { three temperate } \\
\text { zone species from } \\
\text { N.C. and two } \\
\text { tropical species }\end{array}$ & $\begin{array}{l}\text { Vernberg } 8 x \text { Costlow } \\
\text { (in preparation) }\end{array}$ \\
\hline pugnax & megalops & III B & $\begin{array}{l}\text { populations from } \\
\text { N.C. \& Mass. }\end{array}$ & $\begin{array}{l}\text { VERNBERG \& COSTLOW } \\
\text { (in preparation) }\end{array}$ \\
\hline pingilator & megalops & $\begin{array}{l}\text { doesn't } \\
\text { fit any } \\
\text { described } \\
\text { pattern }\end{array}$ & $\begin{array}{l}\text { populations from } \\
\text { Fla. \& N.C. (or Mass.) }\end{array}$ & $\begin{array}{l}\text { VERNBERG \& COSTLOW } \\
\text { (in preparation) }\end{array}$ \\
\hline pugnax & gill & IV A & $\begin{array}{l}\text { populations from } \\
\text { N.C. }\end{array}$ & Verniberg $(1960)$ \\
\hline pugnax & $\begin{array}{l}\text { mid-gut } \\
\text { gland }\end{array}$ & III A & $\begin{array}{l}\text { populations from } \\
\text { N.C. }\end{array}$ & Vernberg $(1960)$ \\
\hline $\operatorname{rapax}$ & gill & III A & $\begin{array}{l}\text { populations from } \\
\text { Jamaica }\end{array}$ & VERNBERG $(1960)$ \\
\hline rapax & $\begin{array}{l}\text { mid-gut } \\
\text { gland }\end{array}$ & I & $\begin{array}{l}\text { populations from } \\
\text { Jamaica }\end{array}$ & Vernaerg $(1960)$ \\
\hline pugilator & brain & II B & $\begin{array}{l}\text { populations from } \\
\text { N.C. }\end{array}$ & $\begin{array}{l}\text { VERNBERG \& VERNBERG } \\
\text { (unpublished) }\end{array}$ \\
\hline pugilator & muscle & $\operatorname{III~B~}$ & $\begin{array}{l}\text { populations from } \\
\text { N.C. }\end{array}$ & $\begin{array}{l}\text { VERNBERG \& VERNBERG } \\
\text { (unpublished) }\end{array}$ \\
\hline pugilator & heart & IV C & $\begin{array}{l}\text { populations from } \\
\text { N.C. }\end{array}$ & $\begin{array}{l}\text { VERNBERG \& VERNBERG } \\
\text { (unpublished) }\end{array}$ \\
\hline
\end{tabular}


BERG (1959). Populations of $U$. pugilator from Massachusetts consumed oxygen faster than a population sample from Florida. Cold- and warm-acclimated $U$. rapax from Jamaica displayed similar metabolic responses to temperature at lower temperatures; at higher temperatures the cold-acclimated animals had a higher rate. In contrast a more northern population of $U$. rapax, living in a sub-tropical region, had a distinctly

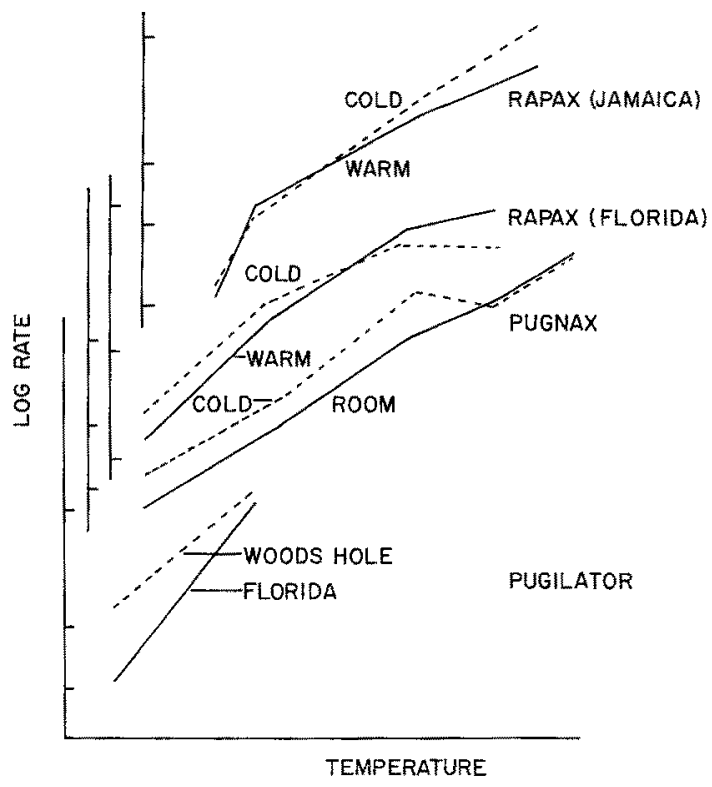

Fig. 5: The comparative metabolic-temperature curves of adult crabs of various populations and species of fiddler crabs

different pattern; at lower temperatures the cold-acclimated forms had higher Q02's and at higher temperatures the warm-acclimated animals had the higher rate. Thus, physiological diversity can be observed within one species. A temperate zone species, $U$. pugnax, had still another pattern of response; at low and intermediate temperatures the cold-acclimated animals had higher metabolic rates, but at high temperatures the response was similar. The work of TAsHIAN (1956) further demonstrated that $M-T$ curves of fiddler crabs from various geographical areas are dissimilar.

A system of classification of patterns of acclimation of rate function to temperature was proposed by Prosser (1958). Briefly the different patterns are as follows: Type I: No adaptation; cold- and warm-acclimated animals have similax responses. Type II: Translation; the M-T curve of cold-acclimated animals is displaced either to the left or to the right of the curve of the warm-acclimated animals. Type III: Rotation; the M-T curves may intersect as a result of a change in the $Q_{10}$ values. Type IV: Translation and Rotation; in certain cases the intersection of the two M-T curves may be observed only by extrapolation and may occur outside the range of normal temperature tolerance. Four variations of this type were described. See also page 442 of this volume. 
Certain generalizations can be made if this system of classification of PROSSER's is applied to the studies on adult and larval $U c a$ as well as their tissues (Table 1). The pattern of acclimation in $U c a$ is not the same in all stages of the life cycle of the species. Moreover, a uniform relationship between latitudinal distribution of all species and pattern of response is not evident. That is, all the southern populations of different species of $U c a$ do not exhibit the same pattern nor do all the northern

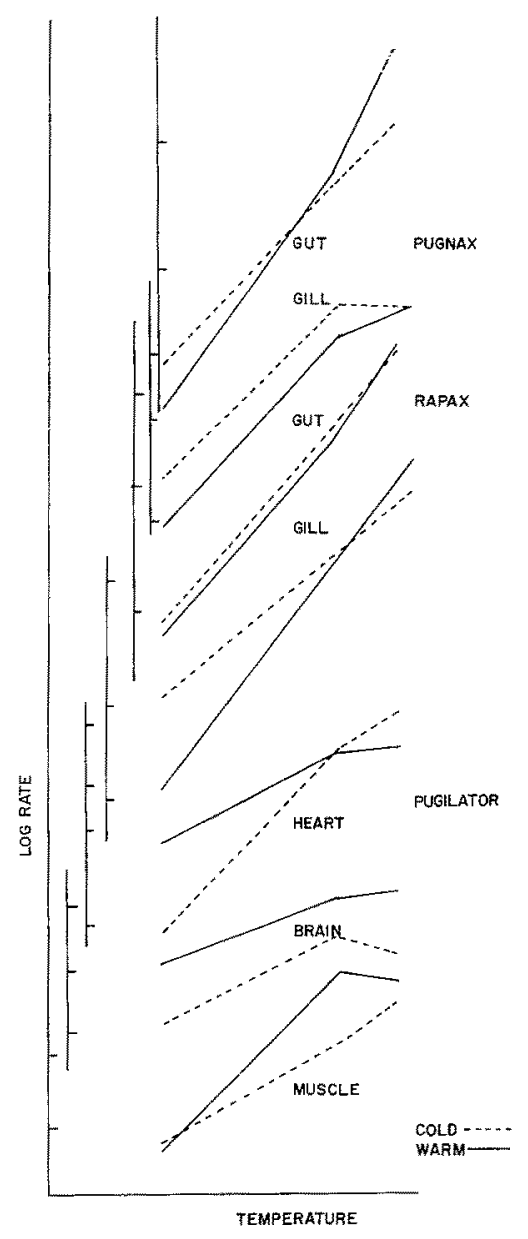

Fig. 6: The comparative metabolic-temperature curves of tissues of various species of tropical and temperate zone fiddler crabs

populations. The pattern has to be determined for each species and cannot be postulated from a generalized relationship. Because different patterns are observed in latitudinally separated populations, inherent physiological differences have apparently taken place during the evolution and distribution of a species.

The description of patterns of acclimation is of significance in that they permit some speculation concerning biochemical mechanisms. Prosser (1958) has described 
the biochemical implications of the different patterns which includes such possibilities as change in enzyme activity, change in activation energy, or shift between alternate enzymatic pathways. Detailed studies of these various biochemical alternatives should greatly improve our understanding of the quantitative biology of metabolism during thermal acclimation. By investigating populations of animals from different latitudes, comparative information on metabolic patterns of response should shed light on the mechanism or mechanisms involved.

Tissues: To attempt to understand mechanisms involved in temperature acclimation the question may be asked if the response of the tissues is the same as that of the whole animal. If acclimation to temperature is not a general cellular response representing one pattern, then one suggestion might be that certain regulatory mechanisms coordinate the response exhibited by the whole organism. Although work on tissues of $U_{c a}$ is in the preliminary stages, M-T curves of some tissues from warm- and coldacclimated animals of certain species are available (Fig. 6) (VERnBERg 1960).

Gill tissue from warm- and cold-acclimated North Carolina animals displayed a similar response (Pattern IV A) as did the whole organism. But a different pattern for mid-gut gland was observed (III B). Neither gill tissue nor mid-gut gland from warm- and cold-acclimated $U$. rapax gave the same response pattern as for the whole organism: gill tissue was pattern III A; mid-gut gland, $\mathrm{I}$; and the whole organism, III $B$. In preliminary studies of a third species, $U$. pugilator, we have found that the heart, supraesophageal ganglion (the "brain"), and muscle each had a different pattern and all were different from that of the whole animal (Fig. 6). The patterns are IV C, II B, III B, and II A respectively. From these data all tissues apparently do not behave metabolically the same as the whole organism during thermal acclimation.

\section{SUMMARY}

1. The present paper reviews certain quantitative aspects of the physiological characteristics of animal populations from different latitudes. Special emphasis is placed on decapod crustaceans of the genus $U c a$, the fiddler crabs.

2. Metabolic characteristics, determined over a graded temperature series and under different conditions of thermal acclimation, are given for larvae and adults of tropical and temperate zone species. Patterns of thermal acclimation according to Prosser's system may be different for each stage of development. No consistent pattern appears to be typical of either tropical or temperate zone species or for different latitudinally separated populations of the same species.

3. The patterns of metabolic-temperature response of various tissues ("brain", muscle, gill, heart, and mid-gut gland) are not all the same as the response of the whole organism.

\section{LITERATURE CITED}

Costlow, J. D., JR., Booknout, C. G. \& Monzoe, R., 1960. The effect of salinity and temperature on larval development of Sesarma cinereum (Bosc) reared in the laboratory. Biol. Bull., Woods Hole 118, 183-202, 
Demeusy, N., 1957. Respiratory metabolism of the fiddler crab Uca pugilator from two different latitudinal populations. Biol. Bull., Woods Hole 113, 245-253.

Fox, H. M., 1936. The activity and metabolism of poikilothermal animals in different latitudes. I. Proc. zool. Soc. Lond. 1936, 945-955.

- 1939. The activity and metabolism of poikilothermal animals in different latitudes. V. Proc. zool. Soc. Lond., Ser. A 109, 141-156.

- \& Wingfield, C. A., 1937. The activity and metabolism of poikilothermal animals in different latitudes. II. Proc. zool. Soc. Lond, Ser. A 107, 275-282.

Goodrodr, I., 1961. Mass mortality of a marine fauna following tropical rains. Ecology 42, $150-155$.

Grundaum, B. W., Siegel, B. V., Schulz, A. R. \& Kirk, P. L., 1955. Determination of oxygen uptake by tissue grown in an all glass differential microrespirometer. Mikrocbimica Acta $1955,1069-1075$.

Mellanby, K., 1940. The activity of certain Arctic insects at low temperatures. J. Anim. Ecol. 9, 296-301.

Mrller, E. M., 1940. Mortality of fishes due to cold on the southeast Florida coast, 1940. Ecology 21, 420-421.

Prosser, C. L., Editor, 1958. Physiological Adaptation. Amer. Physiol. Soc., Washington D. C., $185 \mathrm{pp}$.

SPÄRCK, R., 1936. On the relation between metabolism and temperature in some marine lamellibranches, and its zoogeographical significance. Biol. Medd. Kbh. 13, No. 5, 1-27.

Storey, M. \& Gudger, E. W., 1936. Mortality of fishes due to cold at Sanibel Island, Florida 1886-1936. Ecology 17, 640-648.

TAKATSUkI, S., 1928. The heart pulsation of oysters in tropical seas compared with that of those living in seas of the temperate zone. Rec. oceanogr. Wks Jap. 1, 102.

TASHIAN, R. E., 1956. Geographic variation in the respiratory metabolism and temperature coefficient in tropical and temperature forms of the fiddler crab, Uca pugnax. Zoologica 41, $39-47$.

Thorson, G., 1936. The larval development, growth, and metabolism of arctic marine bottom invertebrates compared with those of other seas. Medd. Gronland 100, No. 6, 1-155.

VERNBERG, F. J., 1959. Studies on the physiological variation between tropical and temperate zone fiddler crabs of the genus Uca. III. The influence of temperature acclimation on oxygen consumption of whole organisms. Biol. Bull., Woods Hole 117, 582-593.

- 1960. The influence of temperature on the tissue metabolism of fiddler crabs from the temperate and tropical zones. (Abstr.) Anat. Rec. 137, 399.

- 1962. Comparative physiology: Latitudinal effects on physiological properties of animal populations. Ann. Rev. Pbysiol. 24, 517-546.

- \& Costrow, J. D., in preparation. Studies on the physiological variation between tropical and temperate zone fiddler crabs of the genus Uca. Respiration of larvae at different temperatures (unpublished).

Welds, H. W., 1961. The fauna of oyster beds, with special reference to the salinity factor. Ecol. Monogr. 31, 239-266.

\section{Discussion following the paper by VernBerg \& VernBerg}

KRÜGER: Ich kenne lhre sehr interessanten und wichtigen Untersuchungen über Uca aus dem Biological Bulletin. Ich habe versucht, sie mit der von mir vorgeschlagenen Temperaturfunktion auszuwerten. In einer Reihe von Fällen scheint es mir möglich zu sein, sie mit der neuen Funktion darzustellen. Man würde dann zu Parametern kommen, die den Kurvenverlauf charakterisieren, und könnte dann diese Parameter vielleicht zur Charakterisierung des KlimaEinflusses auswerten. Die Beschäftigung mit den Wachstumsproblemen hat mich leider daran gehindert, diese Auswertung zum Abschluß zu bringen.

VERNBERG: I would like to learn your new technique of plotting mathematic expressions of temperature-rate functions. 
WIESER: You have shown that in the small zoea larvae the warm-acclimated animals have a higher metabolism than the cold-acclimated ones, whereas in the young adults the reverse holds true. Could it be that this is so because the larvae have a relatively larger surface and therefore can ayail themselves of more oxygen than the adults?

Vernberg: This is possible. However, it should be noted that the first stage zoea have not been acclimated for as long a period as the megalops and young crabs.

RoBERTs: Is there a possibility that in observing the higher metabolism of warm-adapted (N. Carolina) zoea stages as opposed to cold-adapted (Massachusetts) stages, that this might be due to more frequent molting by the warm-climate animals and reflect molting metabolism?

VERNBERG: At $25^{\circ} \mathrm{C}$ the rate of molting appears to be similar in northern and southern forms. The animals from the different regions are used in the same stage of molting.

GRAINGER: To what extent have differences in body size (for the same developmental stage) with latitude complicated results?

VERNBERG: Larvae from the north are larger than ones from the south based on nitrogen. However, influence on respiration is not clear. In Uca pugilator, southern forms are higher than northern forms, but relationship was reversed in case of $U$. pugnax.

KinNe: Have you attempted to differentiate between non-genetic and genetic components of the adaptations reported? Long-term rearing experiments on individuals from different localities may here prove very useful.

VernBERG: By rearing studies, we hope to be able to have animals grown at different temperatures so we can determine genotypic limits. Rearing experiments are in progress now.

KINNE: And how about transplantation experiments?

VERNBERG: No transplantation studies have been made. Jamaica animals will not survive at the low temperatures of Beaufort, North Carolina. Evidence from field studies show that Florida species are killed off by cold winters. 